\title{
The Finnish Sami Population
}

\author{
RIITTA AUVINEN
}

Research Director, Docent

The Population Research Institute

\section{The ethnic background of the Sami people}

The concept "Sami» (»saamelainen» in Finnish), which is widely used today, is based mainly on the ethnicity of a certain population. It is correct to use this concept because the Sami people call themselves »sapmelas», »samit». On the other hand, the concept »Lapp» (»lappalainen» in Finnish) which refers to the region Lappi/Lapland populated by the Sami people has a pejorative sound today when it defines a person (Korpijaakko 1989, 98-99).

The concept »Lapp», »lappalainen», has not even originally been tightly knit to the ethnic origin of a person but to the nature of his livelihood, reindeer herding. This is clearly seen in a situation where a person has changed his profession by giving up his earlier way of breadwinning and has become a farmer, for instance. The time before the change is seen as a time when »he lived as a 'Lapp'» or »in the Lappish way». The ethnic origin of the person is naturally the same, only he isn't a nomad anymore but has become a farmer. Through this use the concept "Sami», "saamelainen" is clearly ethnic by nature. Therefore in this article it is used only in an ethnic context. The concepts »Lapp» and »lappish» can be seen as synonyms meaning the other features of the Sami culture.

The Sami population in Finland, Sweden, Norway and the USSR is an autochtonous population and constitutes an ethnic group with its own background, language and traditional means of subsistence. They also are the only ethnic group in Finland indigenous to the present areas of habitation. Their historical existence is traced back by archeologists to the beginning of the post-glacial period. It is suggested that from the oldest archeological findings in Northern Fennoscandia one can see continuity to the time when the Sami people inhabited the area. This theory states that the present-day Sami descend from the population following the retreating edge of the continental glacier from Europe up to Scandinavia. Their contacts with the proto-Sami population of Finland and East Karelia resulted in the beginning of the Sami culture at the beginning of the first millennium B.C. (Carpelan 1984, 97-108).

It is impossible to distinguish the Sami population as a clearly defined ethnological group on account of their long history of contacts with and absorption by the main populations of the countries in which they live. All of the countries concerned nevertheless include certain nuclear areas of Sami settlement where relatively clear distinguishing criteria may be applied based on ethnic and linguistic characteristics, means of livelihood and life style. In spite of the difficulties encountered, the drawing of a distinction between the Samis and the main population is considered both necessary and inevitable, especially on the part of the Samis themselves, for it is essential in attempts to strengthen the position of a minority group to know precisely to whom any such measures may apply. 


\section{The Lappish territory}

Around a million people live on the North Cape in the region of Sweden, Norway and Finland north of the Arctic Circle. It is not easy to say how many of them are Sami since only Finland has attempted to define what may be called the "Sami ethnic group") and the criteria on which this definition is based are not accepted in either Sweden or Norway. In Finland, until recently, a person who speaks Sami (=Lappish) as his or her primary language or one whose parents or grandparents have learned the Sami language as their first language has been considered to be a Sami (OSF 1970 VI C:104, Vol XVII C, 1974).

Siuruainen and Aikio have in their study »The Lapps in Finland, the population, their livelihood and their culture» $(1977,3)$ briefly drawn the characteristic features of the Sami territory as follows:

- exceptional light conditions with a long period of darkness, »kaamos» in winter and a long light summer

- long, cold winters and short, cool summers

- low annual precipitation

- extensive areas of permafrost and resulting palsa mires and patterned ground

- a long duration of snow cover and total or partial ice cover on lakes and rivers with resulting spring flooding

- a sparse, treeless tundra vegetation, further south stunted forest and coniferous forest

- a sparse fauna and little human settlement as a result of the poor food supply.

By the 19th century the area of concentrated Sami settlement had diminished to practically its present proportions. Movements of the Sami population during the present century have largely been confined within the Sami area, but the same period has seen a major influx of Finns to central and northern Lapland.

Recently major changes have occurred in the extensive area traditionally inhabited by the minority peoples of the northern circumpolar regions. Their customary ways of life, subtly attuned to the ecological conditions of the arctic and sub-arctic areas have become more difficult to pursue as the areas have been settled by more representatives of the dominant populations, exploited for their raw materials and sources of energy by the universal industrial culture and subjected to increasing pressure for leisure activity areas exerted by the growing urban population.

The present phase of adjustment to the dominant cultures is not without its adaptation problems and it has generally been the fate of these groưs to submit in part to the concept of market economy and to the offer of paid employment. In these situations they have frequently been forced to take second place to the dominant peoples because of their deficient language ability, lower standard of education and less committed attitudes. In addition, the areas concerned have often proved too severe climatically for the means of livelihood practiced by the dominant peoples and their settlement has thus been a problematic issue (Siuruainen 1976, 1).

With the exception of migration due to the border alterations or the availability of pasturage for the reindeer, the Sami population has not moved much. Thus if one excludes those Samis from Norway and Sweden who have married in Finland, the parents of the present Sami families were generally both in the municipalities where they now live. This has helped to preserve their sense of identity and cultural stability (Siuruainen 1976, 30). 
Despite its partial absorption into the majority population the Sami municipalities in Finland, Enontekiö, Inari and Utsjoki, continue to grow in numbers of Sami population and maintain and foster their own language, culture and economic practices on a characteristic basis, to the extent that the Finns have gradually begun to appreciate their need for developing a culture and mode of life properly adapted to the prevailing harsh conditions.

The identification of the Sami population with their own area and their own group is based on the minority's history and culture and above all on their own language. If these factors are consciously recognised and emphasized, the identification of the group members will be strengthened.

\section{The Sami language/Lappish as a basis for identification}

Experiencing an identity means much more than merely learning a certain minority role or identifying with one's own ethnic group. Included are the right to live in one's own area of settlement, to speak one's mother tongue and be understood when using it and to foster its position as the language of home, school and literature, as well as that of mass communication. It further means the right to cultivate one's own culture as a frame of reference and support (Asp, Rantanen and Munter 1980, 65). In recent years the Sami population has become aware of this.

The Lappish language belongs to the western branch of the Finno-Ugric languages and is thus related to Finnish. It was mainly during the Bronze Age that the Lappish language grew apart from the Early Proto-Finnic (Valonen 1984, 96). Some conflicting opinions are held concerning the historical relations between these linguistic groups.

Lappish was once isolated from the Pre-Finnic stem within the Finno-Ugrian family of languages. Before this happened the Sami population as identifiable by language has not existed. Earlier, a population including the ancestors of the Lapps must have changed its original »Proto-Lappish» language to a Pre-Finnic one. Carpelan has elaborated a history of »lappification» which is divided into five stages: a Proto (7000-3000 B.C.), a Pre (3000-1000 B.C.), a Primitive (1000 B.C.-A.D. 300), an Early (A.D. 300-1200) and a Historic Lappish stage. The »lappification» process started in eastern Fennoscandia during the Pre-Lappish stage. The population of northern Fennoscandia became Lappish through acculturation in the beginning of the Primitive stage, i.e. the Later Bronze Age (1000-500 B.C.) (Carpelan 1984, 108).

The present Lappish language possesses nine dialects which are mutually comprehensible only with great difficulty. Three of these are spoken in Finland. The total of those speaking Lappish as their mother tongue has been estimated in the year 1977 to be about 18,000, less than 3,000 of them in Finland (Asp, Vakkamaa and Aho 1982, 42).

Administrative and above all regional factors have brought about a situation where Sami people living in different parts of the wide area of Lapland speak different dialects. Three dialects spoken in Finland are Mountain Lappish, Inari Lappish and Skolt Lappish. Mountain Lappish is the prevailing dialect spoken by two-thirds of the Lapps in Finland. Almost one-half of the entire Sami population consider Lappish as their principal language. With the exception of Utsjoki, the most northern municipality in Finland, Lappish does not have the status of the Sami's principal language (Asp, Rantanen and Munter 1980, 16). 
Lappish is used most frequently among reindeer herders over 60 years of age, for whom it provides a convenient vocabulary of traditional specialized terms (Nickul 1970). It has been said that things like areal separation, low education, involvement with reindeer herding and limited geographical and social movement affect the survival of the Lappish language. The withdrawal from their traditional means of livelihood and the increase in wage labor are accelerating the finnicization process.

The Lappish language under the current legislation is not protected by the Finnish Constitution, according to which the only national languages in Finland are Finnish and Swedish. Therefore Lappish is not used as a language of administration or in government offices. It has only a limited use in dealings of an official nature. The lack of a common ortography has long constituted a barrier to the active use of the language.

By force of circumstance many members of the Sami population have had to give up their most essential everyday attribute, their mother tongue, and have therefore begun to identify themselves with the main population and the culture it represents. Schools are considered to have a strong effect on finnicization because instruction is given in Finnish, which has resulted in children learning neither their mother tongue nor Finnish. The children thus handicapped have had less motivation for attending school and have a significantly poorer verbal capacity (Asp, Vakkamaa and Aho 1982, 44). As a result Siuruainen states that the Sami population today is frequently bior trilingual without however achieving a thorough grasp of the skills of speaking, reading or writing in any language (Siuruainen 1976, 32).

In very recent years some progress has been made towards a common written form of language. At the same time other alterations are constantly becoming necessary to enable the Lappish language, which has adapted itself in the past so closely to the ecological sphere of its speakers' occupational structure, to accept the terminology of modern life (Siuruainen and Aikio 1977, 18).

The linguistic integrity of the Sami population has declined everywhere, however, since in many places the children now answer in Finnish when their parents address them in the Lappish language.

The definition of Sami which has been applied in the Finnish censuses earlier was adopted in the 1962 population survey by the Finnish section of the Nordic Lapp Council. It gives Sami status to persons whose parents or grandparents speak or have spoken Lappish as their first language. According to the 1970 general census approximately $51 \%$ of the Sami population in Finland spoke Lappish as their first language, whereas $72 \%$ of the heads of the families had learned it as their mother tongue. Lappish has been retained best in the Mountain dialect-region where there is very little Finnish settlement.

\section{On the history of the Sami population}

The size of the Sami population living in the northern parts of Norway, Sweden and Finland as well as in the Kola peninsula of the USSR is estimated to be greater than ever before. Despite this they constitute an ever smaller national and linguistic minority compared with the main population. Ecological factors such as territory difficult to reach, long distances and a general lack of communications have resulted in the preservation both socially and linguistically of this population.

Actual colonization of the Sami area began towards the end of the 17th century when settlers moving to the area in order to establish farms were promised exemption from taxation for a certain period and exemption from conscription. This colonization gave rise to controversies, however, since the idea of a harmonious co-existence 
between the traditional way of life of the Samis and the newly-introduced agricultural economy proved erroneous in practice, especially in years of crop failure when competition increased for the same natural resources and within the same ecological niches.

Trade and taxation, conversion to Christianity and colonization served to destroy the previously existing economic, social and religious structures and thus led to a breakdown of the Lapp village system, the dispersal of the hunting communities and the abandonment of former territorial rights in the case of fishing as well. Rapid increase took place in the population of Lapland during the period of war in Finland at the beginning of the 18th century and during the years of severe famine in the latter part of the 19th century. The fishing opportunities offered by the Arctic Ocean and the security embodied in the wide variety of food sources available in Lapland attracted large numbers of people from Northern and even Central Finland (Siuruainen 1976, 19).

The increase in the Finnish population of the Sami area was accompanied by a simultaneous decline in contacts between ethnic minority groups in the various Nordic countries. The rhythm of reindeer herding in the mountain region combined with fishing on the coast of the Arctic Ocean which had continued until the mid-19th century came to an end with the closing of the Finnish-Norwegian border to reindeer herders in 1852. A corresponding closure of the border with Sweden in 1889 led to the migration of part of the Enontekiö Sami population to Vuotso, in order to ensure adequate grazing for their reindeer.

Similarly the cession of Petsamo to the Soviet Union after the Second World War led to a permanent transfer of about 450 Skolt Samis of the Orthodox faith to Finland. Alongside these border changes it was the final changeover from temporal grazing of reindeer to the reindeer herding system adopted by the Finns that gradually led end of a »wandering existence living in their 'kota'» in favor of permanent settlement (Siuruainen 1976, 20).

It can be said that the Sami population has in a way been forced in to acculturation. This has mainly been caused by the social value systems and power structures of the main population that are materialized in legislation. The Samis are left with a choice between adapting themselves to the prevailing majority culture on its terms with concomitant material comfort or keeping to the traditional culture with more limited prospects. The result is that the population will prevail in number but will nevertheless decline compared to the majority population. At the same time Lappishness will lose its uniqueness and will tend to merge into the general culture of the country.

On the other hand the fusion of the Lappish areas into a single functional whole and the need for cooperation aroused by the tension of acculturation will reinforce the integration of the Sami community and will tend to retard assimilation (Asp 1965, $3-5)$. The main causes for the cultural anxiety of the Sami population have been as follows: firstly, their historical rights to certain territories in Lapland, secondly, their traditional rights to exploit certain natural resources and thirdly their possibilities to maintain their original culture (Asp, Vakkamaa and Aho 1982, 2-3). The postwar years are usually depicted as the period of the strongest acculturation in the Sami culture.

Ever since the days of its autonomy within Tsarist Russia, Finland has made an effort to ensure the survival of its Sami minority as a linguistic, social and economic entity alongside the main population of the country. Nevertheless, in spite of the endeavors of the numerous state commissions set up for this purpose (e.g. Komiteanmietintö 1905:3, 1938:8, 1952:12, 1973:46, 1985:66) and the detailed bills introduced 
to parliament, Finland still has no legislation recognizing the traditional rights of the Sami population and the equal status of their language. Many conflicting opinions are held on the economic and social differences between the Samis and Finns and many difficult problems remain to be solved in the future.

The Sami population has today perceived this danger and has with a joint effort begun to fend off the mounting pressure of the dominating culture. There has risen a need among the Samis to defend and develop their traditional culture. This has strengthened appreciation of the originality of the group's culture. At the same time spontaneous linguistic or ethnic identification has acquired a new significance. The group is defined by the members of the minority themselves and thus the minority has become the subject of its own future instead of remaining an ethnic object (Asp, Vakkamaa and Aho 1982, 3).

\section{Economic conditions}

The question of the rights of the northern minority peoples over the natural resources of the areas where they have been living has been problematic for centuries. In the case of the Sami population the competition for the rights over areas of land and water has been typical of their existence in all the Nordic countries. All the peoples whose livelihood was dependent upon hunting, fishing or reindeer herding were nomadic peoples moving in groups, whose size was determined according to the organization of these activities.

The sharp distinction between the seasons and reliance upon the natural environment for a living compelled these people to adopt a mobile existence gaining their food largely from hunting, fishing, the trapping of marine mammals and also reindeer herding. Throughout the region it is the waterways that provided food in greatest abundance rather than the land. Very few groups have relied upon a single source of livelihood but most have satisfied their needs from two or three sources in seasonal rotation (Siuruainen and Aikio 1977, 8).

In its most common form, the life of the Sami village followed a seasonal rhythm based on the utilization of land assigned to individual families. The most permanent of their dwelling sites were the winter villages which later became the first to feature $\log$ houses in place of the traditional turf and hide tent structures. The families followed their traditional means of livelihood in their own areas throughout the year with the exception of the winter village period which lasted from November to March. Early in the winter the population began to gather in their winter villages to await what was largely a period of rest and relaxation. This was also the time for family celebrations, traditional games and folk dances as well as intellectual pursuits (Siuruainen and Aikio 1977, 13).

The extension of the economic activities of the majority population into Sami territories has made it more difficult for them to obtain a living in their traditional way, while at the same time insufficient new occupational opportunities have been created to ensure adequate employment and income levels for these people. The recent decades have seen progress made, for instance, in the exploitation of mineral deposits in various parts of the area populated by Samis. More and more countries are placing considerable importance on the resources derivable from these northern regions when planning for an affluent industrial society.

The industrial culture with everything that it implies has extended its boundaries towards the marginal regions of the world, whose original inhabitants possessed an ancient traditional culture which was delicately attuned to the local economic condi- 
tions. Since the Second World War, in particular, development seems to have been leading towards a common universal culture typified by the abandonment of local means of livelihood, widespread urbanization and a loosening of the bond between man and nature almost to the extent of a complete divorce of interest (Siuruainen 1976, 7).

This kind of development is felt severely by the Sami population, which has succeeded in adapting its way of life during several hundreds or even thousands of years to conform to the ecological interaction between man and nature. The need for rapid adaptation to deeply changed circumstances means the breaking down of a whole universe of traditional values of the Sami people, the possible acceptance of new ways of life and a danger for their identity.

\section{Population development of the Samis}

The Sami population has been growing throughout its known history. Erikson states that the whole Polar region in Sweden and Finland was populated in the Middle Ages only by Sami people. At the end of the 13th century in the large Sami area of Sweden and Finland, on the 'lappmarker' of 205,000 km² there lived 1,760 Sami persons. In the year 1553 2,060 Samis were counted (Erikson 1984, 111).

It is possible on the basis of the taxation statistics, the church registers and reports obtained from the local priests to study the population history of the Sami area from the 16th century up to the present day, although it is only from 1750 onwards that the literature contains population figures for the Lappish and Finnish inhabitants side by side. The predominant population trend has been an increase in absolute figures for both populations but with a decline in the proportion of Samis to Finns (Siuruainen 1976, 27).

The migration of the Finns to Lapland has been accompanied by a gradual reduction in the size of the Sami area. It has been estimated that in the 18th and 19th century and especially during the Great Famine Years in the 1860s, hundreds of Finns moved to Ruija by the Arctic Ocean to fish. Many of them stayed permanently in Lapland, mainly in the important Sami villages. For instance, in Inari there were Finns in the years $1800-1900$ as follows: 18 in the year 1800,179 in 1850 and 585 in 1900. The number of Finns in Inari exceeded the Sami population already in the year 1915 (Erikson 1984, 111).

The principal migration of the Sami population during known history has been that of the Enontekiö Samis to the Sompio Lapp area in Vuotso in the 1880s and the movement of the Petsamo Skolt Samis to the the municipality of Inari after the Second World War. It is worth noting that during the first decade of the present century the Sami settlement declined to the point of insignificance in the municipalities of Kittilä and Muonio. The reduction in the Sami area has now proceeded to the extent that Siuruainen sees only the municipalities of Enontekiö, Inari and Utsjoki to be still populated by Samis in Finland (Siuruainen 1976, 27).

Because of the difficulty of exact definition, the estimates of the Sami population and its size given by different sources show wide fluctuations. The most quoted figures are a total of some 35,000 Samis of which 20,000 live in Norway, 10,000 in Sweden, 4,000 in Finland and 1,000-2,000 in the Soviet Union. But Siuruainen, for instance, has estimated in 1977 that with a more liberal interpretation one might arrive at figures ranging from 70,000 to as many as 300,000 .

Estimates of the number of Samis fluctuate nowadays most frequently between 30,000 and 50,000 . The total number of the Sami population has risen considerably 
in the studies and committee reports in the 1970s. A Swedish committee report »Samerna i Sverige» sets the figure at 50,000 (SOU 1975, 99, 37) and a Finnish report of the Lapp Commission (Komiteanmietintö 1973: 46, 165) as high as 70,000.

A program to determine exactly the extent of the Sami population in the Nordic countries was iniated in 1959 by the Nordic Council at the instigation of the Samis themselves. This task was begun in Finland, where it was supposed that it could be carried out easily, but in consequence a vast amount of painstaking work was performed in 1962 to determine the actual Sami population in Finland. The census was carried out chiefly on linguistic ground, taking into account at the same time the opinion of the people interviewed on whether they considered themselves Samis by extraction.

Population censuses confined to the identity criterion have usually arrived at a figure of about 2,500 Samis in Finland, but due to the strict language as distinguishing criteria the census of 1985 has set the figure at 1,698 (OSF 1985 VI C:107). The Sami register set up in Finland in 1962 usually gives higher numbers than the official census due to a more ambigious definition of the Sami population. In any case, about $90 \%$ of the Sami population reside in the present Sami area of northern Lapland, the remainder living in the areas to which they were evacuated during the Second World War or in the towns of southern Finland.

The Sami population of northern Lapland is geographically a very stable one with the majority of the present family members having been born in their current municipalities of residence. Migration from the Sami area has become a significant factor only in more recent years with the increase in educational opportunities and the continued onesidedness of the occupational structure. The main drift has been towards the towns of southern Finland and to Sweden and Norway.

Until recent years Finnish Lapland has enjoyed a steady growth in population. The same has been true for the Sami population measured in absolute numbers. The present Sami area is some $30,000 \mathrm{~km}^{2}$ in extent. The population is concentrated mainly in the municipality centers and larger villages, with the mean population density being only about 0.5 inhabitants per $\mathrm{km}^{2}$. The relative decrease of the Sami population in their own area during the last hundred years is seen in Table 1.

\section{The fertility of the Sami population}

During the last ten years there has been a growing consciousness about the declining birth rate in Finland. The province of Lapland has still, however, been able to renew

Table 1. Population of the Finnish municipalities with major Sami population during the period $1860-1985$

$\begin{array}{rrrrc}\text { Year } & \text { Samis } & \text { Finns } & \text { Total } & \text { Samis \% } \\ 1860 & 964 & 760 & 1,724 & 56.0 \\ 1900 & 1,369 & 1,429 & 2,923 & 46.8 \\ 1910 & 1,567 & 1,844 & 3,444 & 45.5 \\ 1920 & 1,471 & 1,848 & 3,482 & 42.2 \\ 1930 & 1,611 & 2,284 & -3,900 & 41.3 \\ 1940 & 1,695 & 3,340 & 5,297 & 32.0 \\ 1948 & 2,260 & 4,932 & 7,323 & 30.9 \\ 1970 & 3,540 & 7,181 & 10,651 & 33.2 \\ 1985 & 1,408^{*} & 9,805 & 11,213 & 12.6\end{array}$

* new census definition 
Figure 1. Population structure of the Samis and the whole of Finland in 1985.
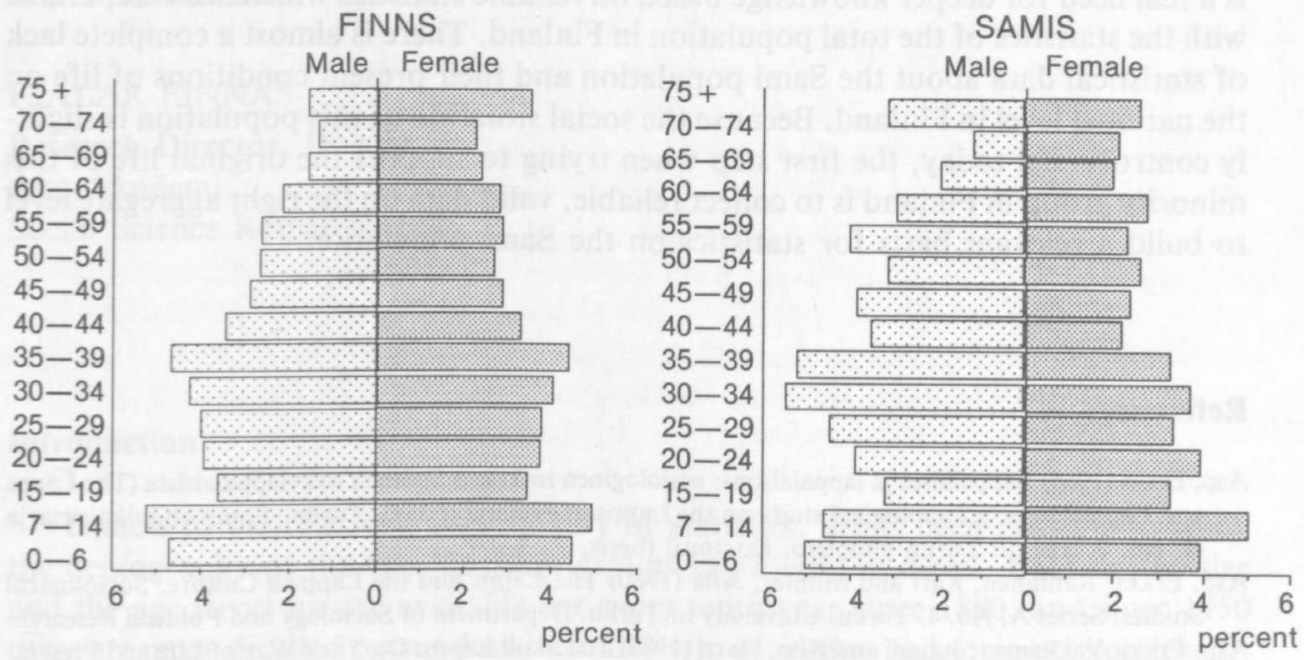

its population. Although the reproduction trend has been declining there, as in the whole Finland, the northern municipalities have had a positive reproduction rate.

Demographically the population of Lapland differs from the rest of the Finnish population by having a birth rate which is slightly higher than average. And the Sami population still deviates from the total population of Lapland by having the highest birth rate in Finland and a rather high proportion of the younger age groups. Other characteristic features of the Sami population are its predominance of males and their rather low marriage rate. These features are clearly seen in the population pyramid of the Sami people when compared with the population pyramid of the whole of Finland in the year 1985 (Figure 1).

The Sami population still differs as to certain demographic features, although the general trend is towards gradual conformity. Because the birth rate among the Samis is above the average in Finland, the average family size is about 5 persons as compared with about 3 in Finnish families. The still prevailing close ties between family members are one explanation for this phenomenon. The highest average family sizes are recorded in the more remote areas (Siuruainen and Alkio 1977, 30).

As a result of powerful family bonds the Sami families often comprise two or three generations under one roof (Siuruainen 1976, 30). It must be noticed, howev$\mathrm{er}$, that one reason for this lies in the housing legislation concerning the Sami population.

When the Sami population is compared with the total population of the municipalities of Enontekiö, Utsjoki and Inari, its own social surroundings, it can be noticed that the population between $0-14$ years comprises $18.2 \%$ of the Sami population but only $17.0 \%$ of the total population of these three municipalities.

However, very little can be said about the fertility trend of the Sami population because consistent information based on numerical data is so sparsely found in the official statistics collected in Finland by the Central Statistical Office. The identification of the new-born children based on the language spoken does not produce reliable information about the real life situation of the Sami population. 
For evaluating the vitality of the present Sami culture, better statistical data is essential. In order to describe the present conditions of the Sami population, there is a real need for deeper knowledge based on reliable statistics which are comparable with the statistics of the total population in Finland. There is almost a complete lack of statistical data about the Sami population and their present conditions of life on the national level in Finland. Because the social situation of this population is slightly controversial today, the first step when trying to support the original life of this minority group in Finland is to collect reliable, valid data on the right aggregate level to build a relevant basis for statistics on the Sami population.

\section{References}

Asp, Erkki (1965) Lappalaiset ja lappalaisuus: sosiologinen tutkimus Suomen nykylappalaisista (The Lapps and Lappishness: a sociological study on the Lapps of Finland today). Turun yliopiston julkaisusarja C, No. 2. Turku: Turun yliopisto. Doctoral thesis.

Asp, Erkki; Rantanen, Kari and Munter, Aila (1980) The Lapps and the Lappish Culture. Sociological Studies, Series A, No. 4. Turku: University of Turku. Department of Sociology and Political Research.

Asp, Erkki; Vakkamaa, Juhani and Aho, Harri (1982) The Skolt Lapps: On Their Way of Life and Presentday Living Conditions. Sociological Studies, Series A, No. 6. Turku: University of Turku. Department of Sociology and Political Research.

Carpelan, Christian (1984) Katsaus saamelaisten esihistoriaan (On the prehistory of the Lapps). In: Suomen väestön esihistorialliset juuret. Tvärminnen symposiumi 17.-19. 1. 1980. Bidrag till kännedom av Finlands natur of folk. Utgiven av Finska Vetenskaps-Societeten, H. 131. Pp. 97-108. Helsinki: Societas Scientiarum Fennica.

Eriksson, Aldur (1984) Saamelaisten perinnölliset erikoispiirteet (On the genetic characteristics of the Lapps). In: Suomen väestön esihistorialliset juuret. Pp. 109-136. Helsinki: Societas Scientiarum Fennica.

Komiteanmietinnöt (Committee reports) 1905:3, 1938:8, 1952:12, 1973:46, 1985:66.

Korpijaakko, Kaisa (1989) Saamelaisten oikeusasemasta Ruotsi-Suomessa: oikeushistoriallinen tutkimus Länsi-Pohjan maankäyttöoloista ja -oikeuksista ennen 1700-luvun puoliväliä (On the legal status of the Samis in the kingdom of Sweden: historical study on the land use circumstances and rights of Länsi-Pohja Lapland before the first half of the 18 th century). Lapin korkeakoulun oikeustieteellisiä julkaisuja. Sarja A, nro 3. Helsinki: Lakimiesliiton Kustannus. Doctoral thesis.

Nickul, Karl (1970) Saamelaiset kansana ja kansalaisina (The Samis as a people and citizens). Suomalaisen Kirjallisuuden Seuran toimituksia 297. Helsinki: Suomalaisen Kirjallisuuden Seura.

OSF (Official Statistics of Finland (1974) 1970 VI C:104, Vol. XVII C Saamelaiset. Helsinki: Central Statistical Office of Finland.

OSF (Official Statistics of Finland) 1985 VI C: 107 (unpublished tables). Helsinki: Central Statistical Office of Finland.

Siuruainen, Eino and Aikio, Pekka (1977) The Lapps in Finland: the Population, Their Livelihood and Their Culture. Series No. 39. Helsinki: Society for the Promotion of Lapp Culture.

Siuruainen, Eino (1976) The Population in the Sami Area of Finnish Lapland. Acta Universitatis Ouluensis, Series A, Scientiae Rerum Naturalium, No. 40. Oulu: University of Oulu. Doctoral thesis.

SOU (1975) Sveriges offentiliga utredningar: Samerna i Sverige.

Valonen, Niilo (1984) Vanhoja lappalais-suomalaisia kosketuksia (Early evidence for points of contact between the Lapps and the Finns). In: Suomen väestön esihistorialliset juuret. Pp. 73-96. Helsinki: Societas Scientiarum Fennica. 